\title{
Stress as a Risk Factor for Multiple Sclerosis Onset or Relapse: A Systematic Review
}

\author{
Artemios K. Artemiadisa, ${ }^{a}$ Maria C. Anagnostoulia Evangelos C. Alexopoulos ${ }^{b}$ \\ a Immunogenetic Laboratory, Department of Neurology, Aeginition Hospital, and b Stress Management and \\ Health Promotion, National and Kapodistrian University Medical School, Athens, Greece
}

Key Words

Multiple sclerosis $\cdot$ Stress $\cdot$ Relapse $\cdot$ Onset

\begin{abstract}
Background: Stress has been considered a triggering factor for multiple sclerosis (MS) since the description of the disease by Jean-Martin Charcot. Until our times, many published studies have supported that both MS onset and relapse could be predisposed by psychological stress. This review aims to synthesize existing knowledge of the relationship between psychological stress and MS onset and relapse, focusing mainly on the quality of observational studies. Methods: We hand-searched MEDLINE with the terms 'stress and multiple sclerosis', using English language restrictions, from January 1980 to November 2010. We included only observational longitudinal studies. The NewcastleOttawa scale proposed by the Cochrane Collaboration was used for assessing the quality of the observational studies. Results: Seventeen publications were analyzed, 5 for MS onset (1 cohort and 4 case-control studies) and 12 for MS relapse ( 9 cohort and 3 case-control studies). We found a marked heterogeneity in stress measurement that mostly targeted the environmental approach to stress. Only 2 publications used radiological criteria for MS relapse. Quality issues were identified mainly for comparability, meaning that studies failed to control adequately for various triggering
\end{abstract}

and psychosocial factors in the stress-MS relationship. Also, selection and blinding problems were identified in most case-control studies. All studies, with only 2 exceptions, resulted in favor of the stress-MS relationship, but due to marked stress measurement heterogeneity, no secure conclusions could be drawn. Conclusions: Future studies should incorporate a multidisciplinary approach to stress measurement and radiological criteria for MS. We further encourage researchers to test the effect of early life stress and stress management techniques on the clinical course of the disease.

Copyright $\odot 2011$ S. Karger AG, Basel

\section{Introduction}

Multiple sclerosis (MS) is an autoimmune demyelinating disease of the central nervous system of unknown etiology. For decades, a significant part of MS research has been focused on possible triggering factors such as infections, toxins, immunizations, nutritional and hor-

A.K.A. and E.C.A. contributed equally to reviewing all the publications and analyzing the data. All authors contributed equally to the interpretation of the results. All the work was coordinated by E.C.A. and M.C.A. The article was written initially by A.K.A. and revised by E.C.A. and M.C.A.

\section{KARGER}

Fax +41613061234 E-Mail karger@karger.ch www.karger.com
(C) 2011 S. Karger AG, Basel

0251-5350/11/0362-0109\$38.00/0

Accessible online at:

www.karger.com/ned
Artemios K. Artemiadis, MD, MSc

Immunogenetic Laboratory, Department of Neurology, Aeginition Hospital

National and Kapodistrian University Medical School

Vassilisis Sofias Avenue 72-74, GR-115-28 Athens (Greece)

Tel. +30 210728 9165, E-Mail artemiad@med.uoa.gr 
monal variables, trauma and sunlight exposure $[1,2]$. Psychological stress is one of the oldest putative factors proposed by the 'father' of clinical neurology, Jean-Martin Charcot [3]. A contemporary report by the American Academy of Neurology declares that 'the relationship between antecedent stress and either MS onset or MS exacerbation is considered possible' [4]. In a more recent meta-analysis of 14 studies, the weighted average effect size (standardized index to measure the strength of the relationship between two variables) of the stress-MS relapse relationship in studies was found to be modest (Cohen's $\mathrm{d}=0.53$; 95\% CI: 0.4-0.65), and it was recommended that no individualized conclusions should be drawn by clinicians [5].

Scientists and common people use the word stress to describe several conditions ranging from environmental threats to psychological responses relevant to anxiety. The prevailing scientific definition is that 'stress is a state in which homeostasis is actually threatened or perceived to be so' [6]. The state of absent homeostasis is also called an 'allostatic state', while the process of returning to homeostasis is also referred to as 'allostasis' [7]. The inappropriate adaptive response from the stress system can lead to a state of distress, cacostasis or allostatic overload, all of which herald the advent of pathology and disease $[6,8]$. The end products or the physiological stress responses such as cortisol, catecholamines, interleukin-6, heart rate and blood pressure serve as biomarkers in basic stress research (biological approach) $[9,10]$. However, in extensive stress research, stress measurement is based on self-report checklists, interviews or diaries that focus either on the incidence of stressors (environmental approach) or on the perceived stressfulness and emotional response to them with anxiety, depression, etc. (psychological approach) [11]. Notably, it has been said that the biological approach is of better prognostic value than the psychological approach - and even better than the environmental one - for disease risk, meaning that biological responses, emotions and perceived stress mediate the stress-disease relationship [11].

So far, published reviews have dealt with studies fragmentarily, except for the meta-analysis mentioned, focusing mainly on results and theoretical conceptualizations [12-15]. To our knowledge, there is a lack of systematic approach in observational studies. Moreover, onset and relapse are reported indiscriminately, while there is evidence that they are pathogenetically different [16]. In this paper, we reviewed studies on stress and MS using a systematic review method, focusing primarily on the quality of studies and, secondarily, on main findings. For these purposes, we included only longitudinal observational studies because of their inherent capacity to address the putative etiological relationship between stress and MS onset and relapse. At the end of this review, pathogenetic mechanisms mediating this relationship are briefly reviewed and updated according to newer concepts of disease pathogenesis.

\section{Methods}

Search Methods and Data Extraction

We hand-searched MEDLINE for articles published in the last 30 years (from January 1980 to November 2010) using English language restrictions. The only search terms used were 'stress and multiple sclerosis'. These criteria firstly served to obtain the most current picture of research on this issue without excluding crucial evidence, and secondly to better assess the probability of this evidence. Contact with authors helped to access full texts and to clarify vague reporting issues. We carefully selected eligible publications by screening titles and abstracts referring to stress and onset or exacerbation/relapse of MS. Search and selection were conducted independently by two medical doctors (A.K.A. and E.C.A.) qualified for biomedical research methodology issues. Classification of observational studies by design was performed independently by the two researchers. Only observational longitudinal studies, either case-control or cohort (follow-up) studies, were included because of their inherent value in distinguishing etiological relations. Publications obtained only in the abstract form were excluded. The references of full-text articles were screened in order to limit the possibility of missing pertinent studies. We independently extracted data concerning criteria for MS diagnosis or relapse, stress measurement methods, additional measures, time periods at risk before MS onset or relapse, duration of studies, selection of participants, number of participants, sex, mean age, mean duration of disease, disability measures (e.g. Expanded Disability Status Scale, EDSS), statistical methods, completeness of studies and results.

\section{Quality Analysis}

Quality measures, assessing the risk of bias, are based on the Newcastle-Ottawa scale for assessing the quality of observational studies recommended by the Cochrane Non-Randomized Studies Methods Working Group (www.cochrane.org) [17]. The Newcastle-Ottawa scale has 3 subscales: selection, comparability and outcome (for cohort studies) or exposure (for case-control studies). On each subscale, studies were allocated stars according to specific criteria adjusted to the needs of this review. Adjustments to the original form are shown in table 1.

Representativeness of normal people for MS onset was evaluated mainly by sample size and, for MS relapse, by the inclusion or not of relapsing-remitting MS (RRMS) cases, which constitute the majority (85-90\%) of MS patients [18]. Small sample sizes in relapse studies were considered somewhat representative. Single major life events or structured validated interviews are both considered valid enough for stress exposure and were allocated stars [11]. Where necessary, modifications to valid measures of MSrelated stress by researchers did not affect the quality of the study, 
Table 1. Newcastle-Ottawa quality assessment scale for observational studies ${ }^{1}$

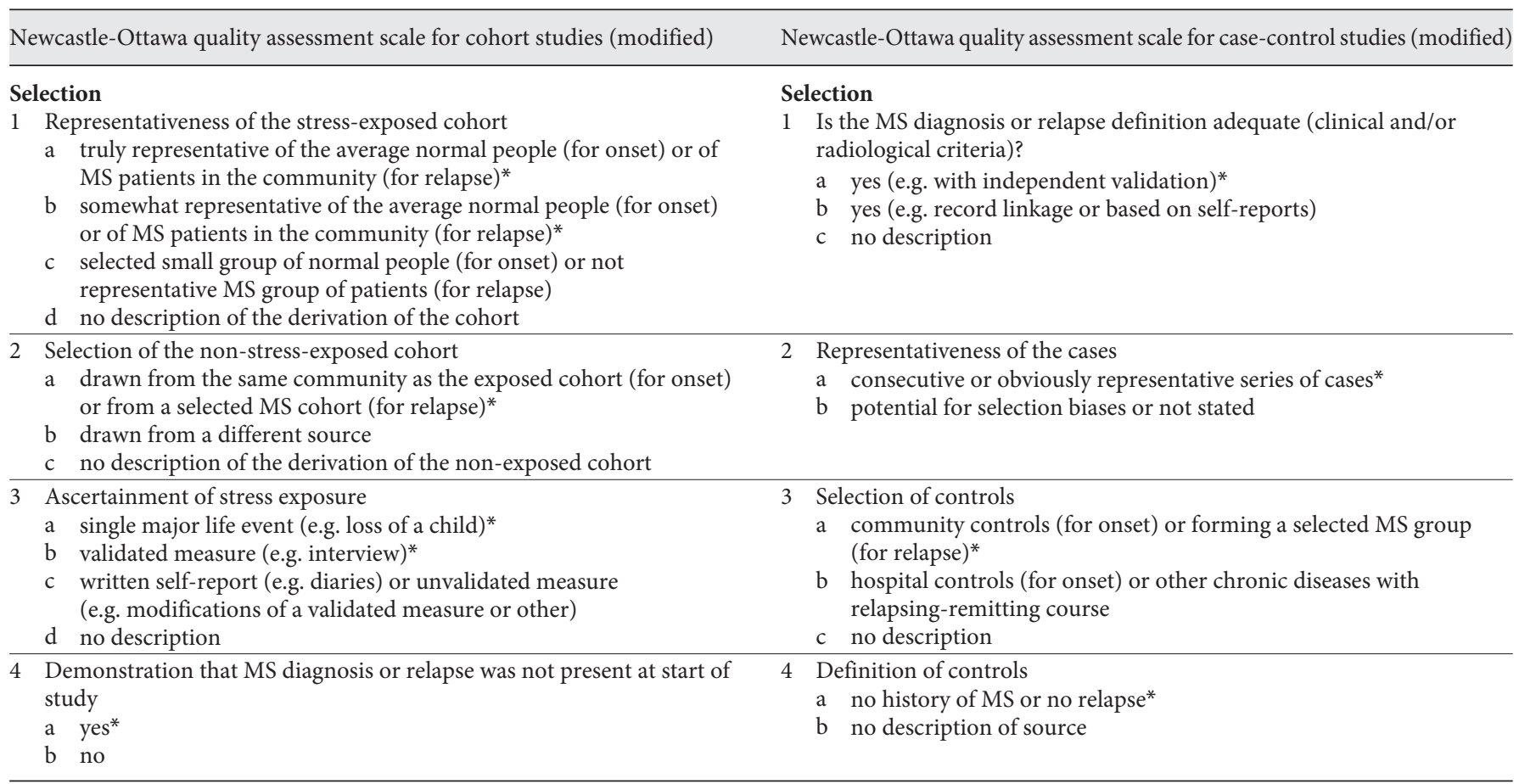

\section{Comparability}

1 Comparability of cohorts on the basis of the design or analysis

a study controls adequately for age or gender or educational level or marital status or residency or disease characteristics*

b study controls adequately for possible triggering factors (e.g. infections) or support or coping or depression or anxiety or optimism or health locus of control*

\section{Comparability}

1 Comparability of cases and controls on the basis of the design or analysis

a study controls adequately for age or gender or educational level or marital status or residency or disease characteristics*

b study controls adequately for possible triggering factors (e.g. infections) or support or coping or depression or anxiety or optimism or health locus of control*

\section{Outcome}

1 Assessment of MS diagnosis or relapse

a independent blind assessment with clinical and/or radiological criteria* $^{*}$

b record linkage*

c self-report or non-blinded assessment

d no description (e.g. for blindness)

\section{Exposure}

1 Ascertainment of stress exposure

a single major life event (e.g. loss of a child)*

b validated measure (e.g. interview) where blind to case/control status*

c validated measure not blinded to case/control status

d written self-report or unvalidated measure (e.g. modified) not blinded to case/control status

e no description of blindness

2 Was follow-up long enough (at least 1 year) for MS diagnosis or relapse to occur (only for clinical criteria)

a yes or radiological criteria for diagnosis*

2 Same method of ascertainment for cases and controls

a yes*

b no

b no

3 Adequacy of follow-up of cohorts

a complete follow-up - all subjects accounted for*

b subjects lost to follow-up unlikely to introduce bias $>80 \%$ follow-up or description provided of those lost*

c follow-up rate $<80 \%$ and/or no description of those lost

d no statement

Note: a study can be awarded a maximum of one star for each numbered item within the Selection and Outcome categories. A maximum of two stars can be given for Comparability.

\section{Non-response rate}

a same rate for both groups*

b non-respondents described

c rate different and no designation

Note: a study can be awarded a maximum of one star for each numbered item within the Selection and Exposure categories. A maximum of two stars can be given for Comparability.

${ }^{1}$ Different criteria for studies referring to onset and relapse are designated in parentheses.* Quality star allocated if condition is satisfied. 
although other types of heuristic change, such as the adoption of rating scales for intensity of stressors, did reduce the quality (see selection question 3). Regarding comparability issues, we constructed two main categories of possible mediators or moderators of the stress-MS relationship: one of sociodemographic or disease factors, and the other of putative factors triggering MS (e.g. infections, exercise, smoking) or psychosocial factors (table 1) [12-15]. Matching, stratification as well as multivariate analysis, and not single correlations or comparisons (e.g. $\chi^{2}$ test, $t$ test), were considered as the most proper methods of controlling for the above factors. We chose the commonly used 1-year follow-up period for MS onset or diagnosis to occur where clinical criteria were adopted (for cohort studies) [19]. This time restriction was not applied to radiological criteria because serial gadolinium-enhanced MRI has shown a development of 20 enhancing lesions each year in the average MS patient [20]. Adequacy of follow-up was checked by the commonly used reference of $80 \%$ completeness. Quality assessments were conducted separately by the authors (A.K.A., E.C.A.) (table 1).

\section{Results}

\section{Findings}

The search for 'stress and multiple sclerosis' resulted in 832 articles, from which we retrieved 26 studies concerning stress and MS, 6 referring to MS onset and the remaining ones to MS relapse [21-46]. Only 1 of the 6 studies concerning onset was designated as a retrospective cohort study [30]. The remaining 5 [23, 39, 44-46] were case-control studies, and 1 of them, by Warren et al. [46], elaborated on the results of a previous publication and was excluded. Regarding MS relapse, 9 studies were designated as cohort studies (follow-up) [26-29, 32-36], 3 as case-control studies [37, 40,43], 5 as cross-sectional studies, and 1 as a case series. The case series [24] (report on exacerbation of MS in 6 female patients undergoing assisted reproductive procedures) and the cross-sectional studies (3 reporting on exacerbation of the disease during a war period [21, 22, 25], 1 denying it [42] and 1 internetbased self-report on stress [31]) were excluded. Two studies in favor of the stress-MS relapse relationship were retained as abstracts, and they were excluded from analysis (citations of the two studies: 28 [38], 4 [41]).

\section{Characteristics of Included Studies}

In total, 245 patients, mainly women approximately in the middle of their 30s, were studied in case-control studies, while the only cohort study used a large sample (table 2). All but one study by Palumbo et al. [39] report valid criteria for MS diagnosis. Stress measurement was mainly focused on the environmental approach to stress, meaning that patients were asked questions about stress- ors in their lives, either in the form of interviews or by record linkage to stressful events such as loss of a child in the cohort study [30]. The only exception were Warren et al. [45], who also asked patients about how unwanted the stress by the stressor they had described was, in relation to their usual experience. Palumbo et al. [39] and Warren et al. [45] were the only research teams that used unvalidated interviews. As seen in table 2, there is limited information about disease duration and disability, with a trend towards below 10 years and limited disability, respectively. Two case-control studies $[39,44]$ focused on stress occurrence 1 year prior to onset of symptoms, one study at 2 years prior to onset [45], and one study at 3 years prior to diagnosis of MS [23].

The total number of patients examined in all MS relapse studies is 775 (429 in case-control studies), mostly patients with a remitting-relapsing course and females with a mean age of 38.9 years, a mean duration of disease of 8.3 years and a mean EDSS score of less than 6 (excluding common samples among studies or missing or vague data). The duration of follow-up studies was generally above 1 year, and case-control studies examined a period of 3-6 months before relapse. Risk time for relapse was defined differently among follow-up studies and ranged from 2 to 12 weeks (except for the studies by Brown et al. $[28,29]$, which assessed stress in 3-monthly intervals over 2 years), depicting either the rate of stress assessment or the time inserted into the Cox regression models with time-dependent covariates. Two studies used MRI criteria for relapse diagnosis, while the others used only clinical criteria $[35,36]$. Clearly, there is a marked diversity of stress measurements, with the majority of studies using validated tools, except for the studies by Potagas et al. [27] and Buljevac et al. [33], which used only diaries, the study by Gasperini et al. [40], which used an unvalidated measure of stress, and the two published studies by Mohr et al. $[35,36]$, which used a modified version of the Social Readjustment Rating Scale (SRRS). All studies focused on the environmental approach to stress, except for Mohr et al. [36], who measured psychological distress, and another study by Ackerman et al. [32], which measured cardiovascular reactivity to acute experimental stressors.

\section{Methodological Quality \\ Cohort (Follow-Up) Studies}

Regarding MS onset, the sole retrospective cohort study did not show major problems, except that it did not control for other triggering or psychosocial factors for MS [30]. As for selection criteria for MS relapse, all cohort studies selected patients somewhat representative of the 
average MS patient in their community, meaning mainly relapsing-remitting patients under immunomodulatory therapy. MS patients were interchangeably classified as stress exposed or not across the follow-up time, thus there were no periodical differences across groups. Ascertainment of stress exposure was principally made using validated measures, except for two studies which used written self-reports (weekly diaries) $[27,33]$ and one research group which used a modified version of the SRRS $[35,36]$. Finally, all groups ascertained that MS relapse was not present at the beginning of the study. Most problems were detected in the comparability section (tables 2, 3). Only four studies managed to control for both sociodemographic or disease characteristics and triggering factors or possible moderators of the stress-MS relationship [27$29,35]$. Two studies controlled for only the first category of factors [32, 36], and one for the second category [33]. Two studies did not control (adequately or at all) for any of them [26, 34]. All studies scored a maximum number of stars on the outcome subscale, except for the study by Brown et al. [28, 29], in which only $51 \%$ of the participants had completed the interviews at 24 months. However, researchers performed a weighted analysis and reduced the possible bias in the final results.

\section{Case-Control Studies}

Regarding MS onset studies, all but one gave an adequate definition of MS diagnosis [39]. Two studies were found to be prone to selection bias due to the lack of a consecutive case selection or obviously representative series of cases [39,44]. Only one study used a well-described community control group [44], and two studies used hospital controls $[39,45]$, increasing the risk for bias due to disease characteristics. All controls had no history of MS. Proper comparability was present only for sociodemographic factors. Two studies used validated tools for stress, but the researchers could not be blinded to casecontrol status [23, 44]; one study used nonvalidated tools without blinding [45], and the study by Palumbo et al. [39] used a nonvalidated tool with no description of the blinding procedure. The ascertainment of stress exposure was not considered the same in two studies by Liu et al. [23] and Grant et al. [44] because MS patients having had the disease already for approximately 2 years were asked about stress exposure 3 years and 1 year before MS onset, respectively, while healthy controls were asked about stress exposure during the same time periods before the time of the interview. Thus, the recall bias was different (against the hypothesis tested), and we could also deduct the absence of blinding to disease status. The remaining two studies used unhealthy controls, and so they did not face this problem $[30,45]$. The response rate was not a problem in any of the studies.

As for MS relapse, the relapse definitions were deemed adequate, though unusual, but in the study by Kroencke and Denney [37], questionnaires on symptoms were mailed to patients, increasing the risk for bias. The same study was also prone to bias concerning the representativeness of cases since only patients registered in the $\mathrm{Na}$ tional Multiple Sclerosis Society were included [37]. Selection and definition of controls did not constitute a problem in the three case-control studies, except for the study by Kroencke and Denney [37], in which the definition of controls was dubious for the reason mentioned above. Comparability was adequate only in the Kroencke/Denney study, in contrast to the other two, which did not take into account other factors than age, sex and disability; in case of the study by Warren et al. [43], control for coping and emotional disturbance was inadequate according to our criteria. Two studies used validated tools for stress, but they were not blinded to disease status [37, 43], and the other study [40] used an unvalidated interview without blinding. The method of ascertainment of exposure and the nonresponse rate was not a problem in any of the studies.

Overall, the percentages of both cohort and case-control studies reaching the maximum number of stars for selection (maximum: 4 stars), comparability (maximum: 2 stars) and exposure/outcome (maximum: 3 stars) are the following: 47, 29.4 and 47\%, respectively. Also, selection and exposure problems were identified mostly in case-control studies, where only two studies reached the maximum number of stars for the selection criterion $[40$, 43] (table 3).

\section{Main Results regarding Stress and MS Relationship Studies on MS Onset}

In the study by Liu et al. [23], MS patients reported more negative life events and family problems and less utilization of social support 3 years before disease diagnosis than healthy controls. The MS group suffered more often from negative emotions such as symptoms of depression, anxiety, obsession, phobia, tense interpersonal relationship and somatization disorder, all of which were positively correlated with negative life events and family problem scores, and negatively with utilization of social support. Personality did not differ among groups. In a large retrospective cohort study in the Danish population, parents who had lost a child younger than 18 years were at greater risk of MS (hazard ratio, HR: 1.56; 95\% CI: 
Table 2. Main characteristics of studies concerning stress and MS onset and relapse relationship

\begin{tabular}{|c|c|c|c|c|}
\hline & Study type & Criteria for MS diagnosis & Stress measurement & $\begin{array}{l}\text { Number of participants (male/female, } \\
\text { number or ratio) }\end{array}$ \\
\hline \multicolumn{5}{|c|}{ Studies on stress and MS onset (reverse chronological order) } \\
\hline Liu et al. 2009 [23] & Case-control & Poser & Life Event Scale & 41 patients $(15 / 26)$ vs. 41 healthy $(15 / 26)$ \\
\hline Li et al. $2004[30]$ & $\begin{array}{l}\text { Retrospective cohort } \\
\text { (follow-up; } 16 \text { years) }\end{array}$ & Poser, Allison and Millar & Single stressor (loss of child) & $\begin{array}{l}21,062 \text { exposed parents vs. randomly } \\
\text { selected } 293,745 \text { not exposed parents }\end{array}$ \\
\hline $\begin{array}{l}\text { Palumbo et al. } \\
1998[39]\end{array}$ & Case-control & Lack of bibliographical support & $\begin{array}{l}\text { Structured unvalidated interview } \\
\text { modeled upon DSM-IV }\end{array}$ & $\begin{array}{l}65 \text { patients (25/40) (32 RRMS, } 11 \text { PPMS, } \\
22 \text { SPMS) vs. } 27 \text { unhealthy }(15 / 12) \\
\text { (chronic polyneuropathies) }\end{array}$ \\
\hline Grant et al. 1989 [44] & Case-control & Poser & Life Events and Difficulties Schedule & 39 patients (10/29) vs. 40 healthy $(10 / 30)$ \\
\hline \multirow[t]{2}{*}{$\begin{array}{l}\text { Warren et al. } \\
1982[45]\end{array}$} & Case-control & Schumacher & $\begin{array}{l}\text { Interview based on a modified version } \\
\text { of Social Readjustment Rating Scale; } \\
\text { unwanted stress questions }\end{array}$ & $\begin{array}{l}100 \text { patients }(1 / 2.3) \text { vs. } 100 \text { matched } \\
\text { unhealthy (other neurological and } \\
\text { rheumatologic diseases) }\end{array}$ \\
\hline & $\begin{array}{l}\text { Type of study (duration } \\
\text { or mean follow-up) }\end{array}$ & Relapse criteria & Stress measurement & Risk time period ${ }^{3}$ \\
\hline \multicolumn{5}{|c|}{ Studies on stress and MS relapse/exacerbation (reverse chronological order) } \\
\hline $\begin{array}{l}\text { Mitsonis et al. } \\
2008[26]\end{array}$ & $\begin{array}{l}\text { Follow-up } \\
\text { (mean: } 56.3 \text { weeks) }\end{array}$ & Clinical $^{4}(24 \mathrm{~h})$ & $\begin{array}{l}\text { Weekly diary; Recent Life Changes } \\
\text { Questionnaire }\end{array}$ & 4 weeks \\
\hline $\begin{array}{l}\text { Potagas et al. } \\
2008[27]\end{array}$ & Follow-up (1 year) & Clinical $^{4}(24 \mathrm{~h})$ & Weekly diary & 4 weeks \\
\hline $\begin{array}{l}\text { Brown et al. } \\
2006[28]\end{array}$ & Follow-up (2 years) & $\begin{array}{l}\text { Clinical }^{4} \text { (telephone- } \\
\text { administered questionnaire and, } \\
\text { whenever possible, clinician } \\
\text { involvement; } 48 \mathrm{~h} \text { ) }\end{array}$ & Life Events and Difficulties Schedule & $\begin{array}{l}\text { Multiple times checked ( } 3 \text { monthly } \\
\text { intervals over } 2 \text { years) }\end{array}$ \\
\hline $\begin{array}{l}\text { Brown et al. } \\
2006 \text { [29] }\end{array}$ & Follow-up ( 2 years) & $\begin{array}{l}\text { Clinical }^{4} \text { (telephone- } \\
\text { administered questionnaire and, } \\
\text { whenever possible, clinician } \\
\text { involvement; } 48 \mathrm{~h} \text { ) }\end{array}$ & Life Events and Difficulties Schedule & $\begin{array}{l}\text { Multiple times checked ( } 3 \text { monthly } \\
\text { intervals over } 2 \text { years) }\end{array}$ \\
\hline $\begin{array}{l}\text { Ackerman et al. } \\
2003[32]\end{array}$ & Follow-up (1 year) & $\operatorname{Clinical}^{4}(48 \mathrm{~h})$ & $\begin{array}{l}\text { Psychiatric Epidemiologic Research } \\
\text { Interview; Life Events and Difficulties } \\
\text { Schedule; cardiovascular reactivity to } \\
\text { acute experimental stressor }\end{array}$ & 6 weeks \\
\hline $\begin{array}{l}\text { Buljevac et al. } \\
2003 \text { [33] }\end{array}$ & $\begin{array}{l}\text { Follow-up } \\
\text { (average: } 74 \text { weeks) }\end{array}$ & Clinical $^{4}(24 \mathrm{~h})$ & Weekly diaries & $2,3,4$ and 5 weeks \\
\hline $\begin{array}{l}\text { Ackerman et al. } \\
2002[34]\end{array}$ & Follow-up (1 year) & Clinical $^{4}(48 \mathrm{~h})$ & $\begin{array}{l}\text { Psychiatric Epidemiologic Research } \\
\text { Interview; } \\
\text { Life Events and Difficulties Schedule }\end{array}$ & 6 weeks \\
\hline $\begin{array}{l}\text { Mohr et al. } \\
2002[35]\end{array}$ & $\begin{array}{l}\text { Follow-up (RRMS mean: } \\
50.13 \text { weeks; SPMS } \\
\text { mean: } 77.6 \text { weeks) }\end{array}$ & $\mathrm{MRI}^{5}$ & $\begin{array}{l}\text { Modified Social Readjustment } \\
\text { Rating Scale (by telephone } 24 \mathrm{~h} \\
\text { before monthly MRI) }\end{array}$ & 8 weeks \\
\hline $\begin{array}{l}\text { Mohr et al. } \\
2000[36]\end{array}$ & $\begin{array}{l}\text { Follow-up (RRMS mean: } \\
50.13 \text { weeks; SPMS } \\
\text { mean: } 77.6 \text { weeks) }\end{array}$ & Clinical $^{6} \mathrm{MRI}^{5}$ & $\begin{array}{l}\text { Modified Social Readjustment Rating } \\
\text { Scale - Hassles scale; } \\
\text { profile of Mood States (by telephone } \\
24 \text { h before monthly MRI) }\end{array}$ & Multiple times checked $(4,8,12$ weeks $)$ \\
\hline $\begin{array}{l}\text { Kroencke and } \\
\text { Denney } 1999 \text { [37] }\end{array}$ & Case-control & $\begin{array}{l}\text { Clinical }^{7} \text { (questionnaires } \\
\text { delivered by mail) }\end{array}$ & $\begin{array}{l}\text { Hassles scale; } \\
\text { Uplifts Scale }\end{array}$ & 6 months \\
\hline $\begin{array}{l}\text { Gasperini et al. } \\
1995[40]\end{array}$ & Case-Control & Clinical $^{6}$ & $\begin{array}{l}\text { Structured unvalidated interview } \\
\text { with } 9 \text { stress categories }\end{array}$ & 3 months \\
\hline $\begin{array}{l}\text { Warren et al. } \\
1991[43]\end{array}$ & Case-Control & Clinical $^{8}$ & $\begin{array}{l}\text { Hassles scale; } \\
\text { Uplifts scale }\end{array}$ & 3 months \\
\hline
\end{tabular}

PPMS = Primary progressive MS; SPMS = secondary progressive MS. ${ }^{1}$ Time period checked for stress occurrence before onset of symptoms or diagnosis of MS. ${ }^{2}$ Expanded Disability Status Scale. ${ }^{3}$ Time period checked for stress occurrence before relapse. ${ }^{4}$ Exacerbation was defined as worsening of existing symptoms or appearance of new symptoms lasting more than 24 or $48 \mathrm{~h}$ (according to stress), after at least 30 days of improvement or stability, not associated with fever. ${ }^{5}$ Exacerbation was defined as the presence of 1 or more $\mathrm{Gd}+$ lesions not visible on the previous MR image. ${ }^{6}$ Exacerbation was defined as an increase of 1 point on the
EDSS from the previous examination or more than $24 \mathrm{~h} .{ }^{7}$ Exacerbation phase was defined as a period of less than 6 months during which 1 or more symptoms of MS were continuously present. Chronic patients were defined as those having symptoms persisting more than 6 months, and patients in remission as those having had no symptoms during the previous 6 months. ${ }^{8}$ Exacerbation was defined as the sudden appearance of a symptom typical of MS which may have been new to participants or experienced during a previous relapse. Remission was defined as no symptoms in the previous 6 months. 


\begin{tabular}{|c|c|c|c|c|}
\hline Mean age, years & $\begin{array}{l}\text { Time before onset/ } \\
\text { diagnosis of } \mathrm{MS}^{1}\end{array}$ & $\begin{array}{l}\text { Mean duration of MS } \\
\text { years }\end{array}$ & Mean EDSS score ${ }^{2}$ & Factors adequately controlled for (method) \\
\hline \multirow[t]{2}{*}{37.44 vs. 36.38} & 3 years before diagnosis & 2.53 & Not mentioned & Age, sex, educational level (matching) \\
\hline & & & & $\begin{array}{l}\text { Age, sex, education, residence, family structure } \\
\text { (multivariate analysis) }\end{array}$ \\
\hline 34 vs. 56 & 1 year before onset & 7 & Not mentioned & None \\
\hline 35.6 vs. 35.7 & 1 year before onset & Median time: 2 & 2.2 & Age, sex, marital status, socioeconomic status (matching) \\
\hline Not mentioned & 2 years before onset & $\begin{array}{l}66 \% \text { of patients } \\
\text { developed symptoms } \\
\text { between } 20 \text { and } 39\end{array}$ & $\begin{array}{l}2 / 3 \text {; ambulatory, } \\
\text { either with cane or } \\
\text { without }\end{array}$ & Age, sex, race, residency (matching) \\
\hline $\begin{array}{l}\text { Number of participants } \\
\text { (male/female, number or ratio) }\end{array}$ & $\begin{array}{l}\text { Mean age } \\
\text { years }\end{array}$ & MS duration, years & Mean EDSS score ${ }^{2}$ & Factors adequately controlled for (method) \\
\hline 26 RRMS (0/26) & 33.5 & 6.5 & 0.4 & None \\
\hline 37 RRMS (0/37) & 32.8 & 3.6 & 0.47 & $\begin{array}{l}\text { Duration of disease, infection, anxiety } \\
\text { (multivariate analysis) }\end{array}$ \\
\hline 101 (20/81); 70 RRMS, 31 SPMS & 42.6 & 8.3 & 3.6 & $\begin{array}{l}\text { Multiple sociodemographic factors, MS disability, MS } \\
\text { type, memory scores, smoking (multivariate analysis) }\end{array}$ \\
\hline 101 (20/81); 70 RRMS, 31 SPMS & 42.6 & 8.3 & 3.6 & $\begin{array}{l}\text { Multiple sociodemographic factors, fatigue, MS type, } \\
\text { MS disability, MS therapy, other medications, cogni- } \\
\text { tive function, coping, social support, optimism, health } \\
\text { locus of control, lifestyle factors (multivariate analysis) }\end{array}$ \\
\hline 50 (0/50); 45 RRMS, 5 SPMS & 39.8 & 9.7 & 2.7 & $\begin{array}{l}\text { MS disability, immunomodulatory therapy } \\
\text { (multivariate analysis) }\end{array}$ \\
\hline 73 RRMS (16/56) & 39.9 & 5.2 & 2.6 & Infections (multivariate analysis) \\
\hline 23 RRMS (0/23) & 39.4 & 7.9 & 3 & None \\
\hline $36(14 / 22) ; 17$ RRMS, 19 SPMS & $\begin{array}{l}\text { RRMS: } 39.8 \\
\text { SPMS: } 48.1\end{array}$ & Not mentioned & $\begin{array}{l}\text { RRMS: } 1.6 \\
\text { SPMS: } 5\end{array}$ & $\begin{array}{l}\text { Coping, treatment with interferon (multivariate } \\
\text { analysis) }\end{array}$ \\
\hline 36 (14/22); 17 RRMS, 19 SPMS & $\begin{array}{l}\text { RRMS: } 39.8 \\
\text { SPMS: } 48.1\end{array}$ & Not mentioned & $\begin{array}{l}\text { RRMS: } 1.6 \\
\text { SPMS: } 5\end{array}$ & MS type (stratification) \\
\hline $\begin{array}{l}61(20 / 41 ; \text { separated into } 3 \\
\text { groups })^{7}\end{array}$ & 48.2 & $\begin{array}{l}\text { Exacerbation group: } 6.3 \\
\text { Chronic group: } 15.6 \\
\text { Remission group: } 13.3\end{array}$ & Not measured & $\begin{array}{l}\text { Duration of MS, symptoms of MS, coping (analysis of } \\
\text { covariance) }\end{array}$ \\
\hline $\begin{array}{l}89 \text { RRMS case-control pairs } \\
(27 / 62) \text { (patients in relapse vs. } \\
\text { patients in remission) }\end{array}$ & $35.6 / 35.3$ & $7.4 / 7.9$ & $1.7 / 1.5$ & Age, sex, MS disability (matching) \\
\hline $\begin{array}{l}95 \text { RRMS case-control pairs }{ }^{8} \\
(1 / 2.3)\end{array}$ & $\begin{array}{l}\text { Exacerbation group: } 34 \\
\text { Remission group: } 36\end{array}$ & $\begin{array}{l}\text { Onset between } 20 \text { and } 39 \\
\text { ( } 71 \% \text { for exacerbation } \\
\text { group and } 81 \% \text { for } \\
\text { remission group) }\end{array}$ & $\begin{array}{l}\text { Walking unaided } \\
\text { ( } 74 \% \text { of exacerbation } \\
\text { group and } 83 \% \text { of } \\
\text { remission group) }\end{array}$ & Age, sex (matching) \\
\hline
\end{tabular}


Table 3. Quality assessment of observational studies on stress and MS onset and relapse ${ }^{1}$

\begin{tabular}{|c|c|c|c|c|c|c|c|c|c|}
\hline & Selection 1 & Selection 2 & Selection 3 & Selection 4 & Comparability 1 & $\begin{array}{l}\text { Exposure } 1 \\
\text { Outcome } 1\end{array}$ & $\begin{array}{l}\text { Exposure } 2 \\
\text { Outcome } 2\end{array}$ & $\begin{array}{l}\text { Exposure } 3 \\
\text { Outcome } 3\end{array}$ & Total \\
\hline \multicolumn{10}{|c|}{ Studies on stress and MS onset (reverse chronological order) } \\
\hline $\begin{array}{l}\text { Liu } \\
\text { et al. } 2009 \text { [23] }\end{array}$ & 1 & 1 & $0 \mathrm{c}$ & 1 & 1a & $0 \mathrm{c}$ & 0 & 1 & $\begin{array}{l}\text { selection: } 3 \\
\text { comparability: } 1 \\
\text { exposure: } 1\end{array}$ \\
\hline $\begin{array}{l}\mathrm{Li} \\
\text { et al. } 2004[30]\end{array}$ & 1a & 1 & 1a & 1 & 1a & $1 b$ & 1 & 1a & $\begin{array}{l}\text { selection: } 4 \\
\text { comparability: } 1 \\
\text { outcome: } 3\end{array}$ \\
\hline $\begin{array}{l}\text { Palumbo } \\
\text { et al. } 1998 \text { [39] }\end{array}$ & $0 \mathrm{c}$ & 0 & $0 \mathrm{~b}$ & 1 & 0 & $0 \mathrm{e}$ & 1 & 1 & $\begin{array}{l}\text { selection: } 1 \\
\text { comparability: } 0 \\
\text { exposure: } 2\end{array}$ \\
\hline $\begin{array}{l}\text { Grant } \\
\text { et al. } 1989 \text { [44] }\end{array}$ & 1 & 0 & 1 & 1 & $1 \mathrm{a}$ & $0 c$ & 0 & 1 & $\begin{array}{l}\text { selection: } 3 \\
\text { comparability: } 1 \\
\text { exposure: } 1\end{array}$ \\
\hline $\begin{array}{l}\text { Warren } \\
\text { et al. } 1982[45]\end{array}$ & 1 & 1 & $0 \mathrm{~b}$ & 1 & $1 \mathrm{a}$ & $0 \mathrm{~d}$ & 1 & 1 & $\begin{array}{l}\text { selection: } 3 \\
\text { comparability: } 1 \\
\text { exposure: } 2\end{array}$ \\
\hline \multicolumn{10}{|c|}{ Studies on stress and MS relapse (reverse chronological order) } \\
\hline $\begin{array}{l}\text { Mitsonis } \\
\text { et al. } 2008 \text { [26] }\end{array}$ & $1 b$ & 1 & $1 b$ & 1 & 0 & 1a & 1 & $1 b$ & $\begin{array}{l}\text { selection: } 4 \\
\text { comparability: } 0 \\
\text { outcome: } 3\end{array}$ \\
\hline $\begin{array}{l}\text { Potagas } \\
\text { et al. } 2008 \text { [27] }\end{array}$ & $1 b$ & 1 & $0 \mathrm{c}$ & 1 & 2 & $1 \mathrm{a}$ & 1 & $1 b$ & $\begin{array}{l}\text { selection: } 3 \\
\text { comparability: } 2 \\
\text { outcome: } 3\end{array}$ \\
\hline $\begin{array}{l}\text { Brown } \\
\text { et al. } 2006 \text { [28] }\end{array}$ & $1 \mathrm{~b}$ & 1 & $1 \mathrm{~b}$ & 1 & 2 & $1 \mathrm{a}$ & 1 & $0 \mathrm{c}$ & $\begin{array}{l}\text { selection: } 4 \\
\text { comparability: } 2 \\
\text { outcome: } 2\end{array}$ \\
\hline $\begin{array}{l}\text { Brown } \\
\text { et al. } 2006 \text { [29] }\end{array}$ & $1 b$ & 1 & $1 \mathrm{~b}$ & 1 & 2 & $1 \mathrm{a}$ & 1 & $0 \mathrm{c}$ & $\begin{array}{l}\text { selection: } 4 \\
\text { comparability: } 2 \\
\text { outcome: } 2\end{array}$ \\
\hline $\begin{array}{l}\text { Ackerman } \\
\text { et al. } 2003 \text { [32] }\end{array}$ & $1 \mathrm{~b}$ & 1 & $1 \mathrm{~b}$ & 1 & 1a & $1 \mathrm{a}$ & 1 & $1 \mathrm{a}$ & $\begin{array}{l}\text { selection: } 4 \\
\text { comparability: } 1 \\
\text { outcome: } 3\end{array}$ \\
\hline $\begin{array}{l}\text { Buljevac } \\
\text { et al. } 2003 \text { [33] }\end{array}$ & $1 \mathrm{~b}$ & 1 & $0 c$ & 1 & $1 \mathrm{~b}$ & $1 \mathrm{a}$ & 1 & $1 \mathrm{~b}$ & $\begin{array}{l}\text { selection: } 3 \\
\text { comparability: } 1 \\
\text { outcome: } 3\end{array}$ \\
\hline $\begin{array}{l}\text { Ackerman } \\
\text { et al. } 2002 \text { [34] }\end{array}$ & $1 \mathrm{~b}$ & 1 & $1 \mathrm{~b}$ & 1 & 0 & 1a & 1 & $1 \mathrm{a}$ & $\begin{array}{l}\text { selection: } 4 \\
\text { comparability: } 0 \\
\text { outcome: } 3\end{array}$ \\
\hline $\begin{array}{l}\text { Mohr } \\
\text { et al. } 2002 \text { [35] }\end{array}$ & $1 \mathrm{~b}$ & 1 & $0 c$ & 1 & 2 & $1 \mathrm{a}$ & 1 & $1 \mathrm{a}$ & $\begin{array}{l}\text { selection: } 3 \\
\text { comparability: } 2 \\
\text { outcome: } 3\end{array}$ \\
\hline $\begin{array}{l}\text { Mohr } \\
\text { et al. } 2000[36]\end{array}$ & $1 b$ & 1 & $0 \mathrm{c}$ & 1 & 1a & $1 \mathrm{a}$ & 1 & $1 \mathrm{a}$ & $\begin{array}{l}\text { selection: } 3 \\
\text { comparability: } 1 \\
\text { outcome: } 3\end{array}$ \\
\hline $\begin{array}{l}\text { Kroencke and } \\
\text { Denney } 1999 \text { [37] }\end{array}$ & $0 \mathrm{~b}$ & 0 & 1 & 0 & 2 & $0 \mathrm{c}$ & 1 & 1 & $\begin{array}{l}\text { selection: } 1 \\
\text { comparability: } 2 \\
\text { exposure: } 2\end{array}$ \\
\hline $\begin{array}{l}\text { Gasperini } \\
\text { et al. } 1995 \text { [40] }\end{array}$ & 1 & 1 & 1 & 1 & 1a & $0 \mathrm{~d}$ & 1 & 1 & $\begin{array}{l}\text { selection: } 4 \\
\text { comparability: } 1 \\
\text { exposure: } 2\end{array}$ \\
\hline $\begin{array}{l}\text { Warren } \\
\text { et al. } 1991 \text { [43] }\end{array}$ & 1 & 1 & 1 & 1 & 1a & $0 c$ & 1 & 1 & $\begin{array}{l}\text { selection: } 4 \\
\text { comparability: } 1 \\
\text { exposure: } 2\end{array}$ \\
\hline
\end{tabular}

\footnotetext{
${ }^{1}$ Numbers represent the stars allocated to each question, and letters, where needed, represent the subcategory of questions for which studies were more suitable (see table 1 for guidance).
} 
1.05-2.31) than parents who had not, but this difference was only significant for the 8- to 17-year follow-up period (HR: 2.25; 95\% CI: 1.32-3.81) [30]. Interestingly, the overall risk was nearly twice as high for those parents who had lost their child unexpectedly (HR: 2.13; 95\% CI: $1.13-$ 4.03). The case-control study by Palumbo et al. [39] suggested that although MS patients reported more stressful life events (especially family problems such as serious illness and interpersonal conflicts) for the 1 year preceding onset than patients with chronic polyneuropathies (24.6 vs. $14.8 \%$ ), the difference was not statistically significant. In the study by Grant et al. [44], MS patients more often reported a marked adversity in the year before onset (77 vs. $35 \%$; $\mathrm{p}<0.001)$ than did matched healthy controls, and this excess was most evident in the 6 months before onset. Interestingly, marital, parental and sibling difficulties were reported significantly more frequently by MS patients. In the oldest case-control study, a significantly higher proportion of MS patients reported unwanted stress ( 79 vs. $54 \%$ ) and 3 or more events ( 36 vs. $13.5 \%$ ) in the 2 years preceding onset than did unhealthy controls [45]. Major differences were documented as problems related to family, marriage, pregnancy, finances and change of residency or lifestyle.

\section{Studies on MS Relapse}

One recent follow-up study in Greece showed that 3 or more life events during a 4-week period (HR: 5.36; 95\% CI: $1.74-16.46)$ or at least 1 long-term event lasting at least 10-14 days (HR: 3.03 ; 95\% CI: 1.01-9.13) per month were associated with increased risk of relapse in the following 4 weeks, whereas the number of short-term events, the type and the severity of stressors did not [26]. In a similar study, 3 or more events and not severity were associated with increased rate of relapses (HR: 8.9; 95\% CI: 3.423.5), and not surprisingly, anxiety levels, measured by the Hamilton Rating Scale, were markedly increased with 3 or more stressors per month and severe stressors [27]. In both studies, family/marital and professional/financial problems seemed to have been reported most, but they did not have a significantly different impact on relapse risk [26, 27].

In one follow-up study by Brown et al. [28], acute (lasting less than 6 months) stressor frequency (odds ratio, OR: 1.3 ; 95\% CI: 1.1-1.5), being male (OR: 4; 95\% CI: $1.6-$ 9.8) and disability score (OR: 0.5; 95\% CI: 0.4-0.8) were related to risk of relapse. A bidirectional relation between stress and MS relapse was also documented. In another study in the same group of patients, acute stressor frequency (OR: 1.3; 95\% CI: 1.1-1.4) and coping responses that utilize social support (OR: 1.1; 95\% CI: 1-1.2), but not chronic stressors, disease and demographic, psychosocial (such as depression, anxiety, health locus of control, optimism) or lifestyle factors (such as substance abuse, sleep quality, exercise, relaxation techniques) were found to predict MS relapse [29]. Interestingly, stressors, age, coping and relaxation training accounted for $33-42 \%$ of the variance in relapse occurrence.

A study by Ackerman et al. [32] showed that $42 \%$ of documented life events were associated with exacerbation in the following 6 weeks, and that $30 \%$ of the variance in the proportion of weeks ill was explained by disability level, benzodiazepine usage, cardiovascular reactivity to laboratory acute stress, baseline heart rate and life event density. Severe short-term threat (lasting less than 2 weeks), but not long-term threat (except for severe ones) or type of stressor, were related to MS course. Participants with pronounced autonomic response to acute laboratory stress and increased number of life events were more likely to relapse within 6 weeks. In a similar study by the same group of researchers [34], 85\% of stressors were linked to relapse within 6 weeks, and an increase in frequency of life events was associated with greater likelihood of MS exacerbation (HR: 13.18; 95\% CI: 1.67-104.39).

The follow-up study by Buljevac et al. [33] showed that even the presence of a single stressor renders patients at risk for exacerbation 4 weeks after (relative risk: 2.2; 95\% CI: 1.2-4.0), and interestingly, multiple stressors per month did not provoke a significant increase in the risk.

Mohr et al. [35, 36] conducted two follow-up studies using radiological criteria for the diagnosis of MS relapse. In the most recent one, conflict and disruption in routine (e.g. family or job conflict), a subscale derived from the modified SRRS, was significantly related to increased odds of appearance of new $\mathrm{Gd}+$ lesions 8 weeks later (OR: 1.62; 95\% CI: 1.12-2.34) [35]. Furthermore, the interaction between distraction, as a coping mechanism, and conflict and disruption in routine was significantly related to decreased odds of appearance of new $\mathrm{Gd}+$ lesions 8 weeks later (OR: 0.69; 95\% CI: 0.49-0.98). In contrast, distraction alone was not significantly related to new lesion formation, thus distraction may be a moderating factor in the stress-relapse relationship. The second study came up with similar results regarding conflict and disruption in routine for both RRMS and secondary progressive MS patients (OR: 1.64; 95\% CI: 1.22-2.20) [36]. Surprisingly, psychological distress, which is considered a mediator of the stress-disease relationship, was not related to clinical exacerbation of MS in either group of patients [36]. 
In the most recent case-control study, 61 patients were separated into 3 groups according to clinical symptoms of MS during the study time (table 2) [37]. The subgroups were different with respect to hassle frequency, hassle total intensity scores and use of passive avoidant or aggressive coping. The exacerbation subgroup had higher hassle and coping scores compared with the chronic group, but not compared with the remission group. Controlling for duration of disease and symptoms, the difference in hassle scores remained, but coping as a factor was eliminated. Another case-control study found no relation between 9 categories of 'unusual' stressors and exacerbation of MS [40]. In the last case-control study, relapse patients scored higher on emotional disturbance (questionnaire on somatic symptoms, anxiety, depression and social dysfunction) and intensity of stressful events, but lower on frequency of compensating uplifts, compared to remission patients [43]. There was also a tendency for MS patients in remission to favor emotion-focused coping over problem-solving or social support [43]. However, all these stress-related measures accounted for only $10 \%$ of the variance in exacerbation rates.

\section{Conclusions}

In this review, we tried to elucidate the stress-MS relationship following a systematic approach to the observational longitudinal studies published in the last 30 years in the MEDLINE database. Our conclusions are as follows. Firstly, there are only few studies (26 in total) on the stress-MS relationship in relation to the 30 -year period, the majority of which referring to MS relapse (20 in total). Follow-up studies regarding stress and MS onset are scarce, although for stress and MS relapse, it has been the main study design used for the last 11 years.

Secondly, in general, the stress-MS relationship has been tested in normal or MS subjects representative of the community. The stress measurements were quite heterogeneous and mainly limited to the environmental approach, with three exceptions measuring cardiovascular reactivity to laboratory stress and psychological distress $[32,36,45]$. Perceived stress was not measured in any of the studies. The extended subanalysis of stress measures for different stress aspects discouraged us from conducting a meta-analysis. Diagnosis of MS onset and relapse was mainly clinical, with the exception of one study group, for which radiological criteria were used $[35,36]$. In general, studies on MS onset used a time window above 1 year, while follow-up and case-control studies used a time window below 3 months and above 3 months, respectively, with only one research group exception $[28,29]$.

Thirdly, most studies failed to control for triggering and/or psychosocial factors for the stress-MS relationship. In addition, the case-control studies faced quality problems concerning several aspects of participant selection, whereas blinding of researchers to clinical status posed a big methodological challenge.

Fourthly, all studies were in favor of the stress-MS relationship, with only two exceptions $[39,40]$. The heterogeneity of stress measurements did not allow us to draw any secure conclusions about several stress aspects such as the number, chronicity, type and severity of stressors. Finally, coping seems to arouse the greatest research interest, but results are equivocal.

Information about biological mechanisms mediating the stress-MS relationship mainly comes from animal studies of the experimental autoimmune encephalomyelitis (EAE) model. Acute stress seems to act enhancing prior to EAE induction, but chronic stress acts suppressively both prior to and after EAE induction [47]. This is in accordance with general concepts of the effects of stress on the immune system, according to which (1) acute stress is immunoenhancing and favors both Th1 and Th2 immune responses, and (2) chronic stress is immunosuppressive and there is downregulation of immune responses (mainly the Th1 type, which predominates in MS inflammation), a shift to Th2 responses, dysregulation of the hypothalamic-pituitary-adrenal (HPA) axis and peripheral glucocorticoid resistance [48]. In addition, a hyposensitive and hyporesponsive HPA axis has been documented, mainly due to diminished drive by proinflammatory cytokines in the course of EAE [47].

In MS patients there is a hyperactivity or hyporeactivity of the HPA axis [47]. Notably, the latter has been correlated with a high incidence of hypothalamic lesions and an adverse clinical course [47]. Hyperactivity of the HPA axis is hypothesized to be the result of a shift from corticotropin-releasing hormone to arginine vasopressin peptide production, which is less sensitive to cortisol negative feedback [49]. One other hypothesis is that hyperactivity could be explained by neurodegeneration causing damage by the neural projections of regulatory brain areas (such as the hippocampus and medial prefrontal cortex) on the hypothalamus [49]. This is in accordance with the dexamethasone-corticotropin-releasing hormone test, which shows a decreased HPA feedback correlated with global brain atrophy $[47,49]$. Finally, hyperactivity of the HPA axis often coexists with peripheral glucocorticoid and catecholamine resistance, meaning less control of inflammation [49]. 
Two main limitations of this review are that we searched only the MEDLINE database, and only for studies published since 1980. Thus, there is always the possibility that we have missed studies in other databases and published before 1980. However, we used no specific limits, thus increasing the sensitivity of the search method. We would also like to report that we identified only a few missed studies cited in the papers presented above, most of which were conducted before 1980. In addition, there could always be problems such as publication bias due to underreporting of negative results and gray literature.

Case-control studies are least capable of establishing a causal relationship between stress and MS onset or relapse due to recall bias, information bias caused by diagnosis- or relapse-related stress and making sense ('vagaries in recall') [29, 50-52]. Follow-up studies have to deal with the temporal relationship between stress and MS since clinical criteria for relapse do not always correspond to inflammation processes, and newer brain imaging techniques detect changes at least 1 month before the appearance of clinical symptoms and Gd+ MR images [53-57]. Thus, we recommend Gd-enhancing lesions for relapse diagnosis and a 2-month or lower limit for stress measurement. Additionally, in the absence of a gold standard measure of stress, we recommend a multidisciplinary approach while controlling for putative confounders [11]. Finally, apoptosis of oligodendrocytes early in the course of the disease denotes different noninflammatory pathways accounting for MS onset and relapse $[16,58]$. We raise the hypothesis that the risk of MS could be determined in early childhood when multiple factors such as stress could render oligodendrocytes vulnerable later in life [59-62].

In conclusion, there is evidence that stress can influence MS onset and its clinical course. For that reason, we encourage clinicians to embrace stress and stress management in their clinical decision making and practice with MS patients. We finally hope that this review will encourage researchers to investigate the role of stress management techniques in the clinical course of the disease.

\section{Acknowledgment}

We thank professor George Chrousos for his valuable support for and advice on the conceptualization of stress and stress mechanisms.

\section{Disclosure Statement}

The authors have no conflicts of interest.

\section{References}

1 Casetta I, Granieri E: Prognosis of multiple sclerosis: environmental factors. Neurol Sci 2000;21(4 suppl 2):S839-S842.

$\checkmark 2$ Coo H, Aronson KJ: A systematic review of several potential non-genetic risk factors for multiple sclerosis. Neuroepidemiology 2004; 23:1-12.

3 Charcot JM: Lectures on the Diseases of the Nervous System. London, New Sydenham Society, 1877.

4 Goodin DS, Ebers GC, Johnson KP, Rodriguez M, Sibley WA, Wolinsky JS: The relationship of MS to physical trauma and psychological stress: report of the Therapeutics and Technology Assessment Subcommittee of the American Academy of Neurology. Neurology 1999;52:1737-1745.

5 Mohr DC, Hart SL, Julian L, Cox D, Pelletier D: Association between stressful life events and exacerbation in multiple sclerosis: a meta-analysis. BMJ 2004;328:731.

6 Chrousos GP: Stress and disorders of the stress system. Nat Rev Endocrinol 2009;5: 374-381.

77 Goldstein DS, McEwen B: Allostasis, homeostats, and the nature of stress. Stress 2002;5: 55-58.
8 McEwen BS: Stress, adaptation, and disease: allostasis and allostatic load. Ann NY Acad Sci 1998;840:33-44.

-9 Chrousos GP: Stressors, stress, and neuroendocrine integration of the adaptive response. The 1997 Hans Selye Memorial Lecture. Ann NY Acad Sci 1998;851:311-335.

10 Hellhammer DH, Wüst S, Kudielka BM: Salivary cortisol as a biomarker in stress research. Psychoneuroendocrinology 2009;34: 163-171

11 Cohen S, Kessler RC: Measuring Stress. Oxford, Oxford University Press, 1997.

12 Mitsonis CI, Potagas C, Zervas I, Sfagos K: The effects of stressful life events on the course of multiple sclerosis: a review. Int Neurosci 2009;119:315-335.

13 Mohr DC: Stress and multiple sclerosis. Neurol 2007;254(suppl 2):II65-II68.

14 Mohr DC, Pelletier D: A temporal framework for understanding the effects of stressful life events on inflammation in patients with multiple sclerosis. Brain Behav Immun 2006;20:27-36.

15 Brown RF, Tennant CC, Dunn SM, Pollard JD: A review of stress-relapse interactions in multiple sclerosis: important features and stress-mediating and -moderating variables. Mult Scler 2005;11:477-484

16 Artemiadis AK, Anagnostouli MC: Apoptosis of oligodendrocytes and post-translational modifications of myelin basic protein in multiple sclerosis: possible role for the early stages of multiple sclerosis. Eur Neurol 2010;63:65-72.

17 Wells GA, Shea B, O'Connell D, Peterson J, Welch V, Losos M, Tugwell P: The Newcastle-Ottawa Scale (NOS) for assessing the quality of nonrandomised studies in metaanalyses. Ottawa, Ottawa Health Research Institute, 1999.

18 Flachenecker P: Epidemiology of neuroimmunological diseases. J Neurol 2006;253 (suppl 5):V2-V8.

$>19$ Held U, Heigenhauser L, Shang C, Kappos L, Polman C, Sylvia Lawry Centre for MS Research: Predictors of relapse rate in MS clinical trials. Neurology 2005;65:1769-1773.

20 Thompson AJ, Miller D, Youl B, MacManus D, Moore S, Kingsley D, Kendall B, Feinstein A, McDonald WI: Serial gadolinium-enhanced MRI in relapsing/remitting multiple sclerosis of varying disease duration. Neurology 1992;42:60-63. 
-21 Yamout B, Itani S, Hourany R, Sibaii AM, Yaghi S: The effect of war stress on multiple sclerosis exacerbations and radiological disease activity. J Neurol Sci 2010;288:42-44.

-22 Somer E, Golan D, Dishon S, Cuzin-Disegni L, Lavi I, Miller A: Patients with multiple sclerosis in a war zone: coping strategies associated with reduced risk for relapse. Mult Scler 2010;16:463-471.

-23 Liu XJ, Ye HX, Li WP, Dai R, Chen D, Jin M: Relationship between psychosocial factors and onset of multiple sclerosis. Eur Neurol 2009;62:130-136.

-24 Hellwig K, Schimrigk S, Beste C, Muller T, Gold R: Increase in relapse rate during assisted reproduction technique in patients with multiple sclerosis. Eur Neurol 2009;61: 65-68.

25 Golan D, Somer E, Dishon S, Cuzin-Disegni L, Miller A: Impact of exposure to war stress on exacerbations of multiple sclerosis. Ann Neurol 2008;64:143-148.

26 Mitsonis CI, Zervas IM, Mitropoulos PA, Dimopoulos NP, Soldatos CR, Potagas CM, Sfagos CA: The impact of stressful life events on risk of relapse in women with multiple sclerosis: a prospective study. Eur Psychiatry 2008;23:497-504.

-27 Potagas C, Mitsonis C, Watier L, Dellatolas G, Retziou A, Mitropoulos P, Sfagos C, Vassilopoulos D: Influence of anxiety and reported stressful life events on relapses in multiple sclerosis: a prospective study. Mult Scler 2008;14:1262-1268.

-28 Brown RF, Tennant CC, Sharrock M, Hodgkinson S, Dunn SM, Pollard JD: Relationship between stress and relapse in multiple sclerosis. Part 1. Important features. Mult Scler 2006;12:453-464.

-29 Brown RF, Tennant CC, Sharrock M, Hodgkinson S, Dunn SM, Pollard JD: Relationship between stress and relapse in multiple sclerosis. Part 2. Direct and indirect relationships. Mult Scler 2006;12:465-475.

-30 Li J, Johansen C, Brønnum-Hansen H, Stenager E, Koch-Henriksen N, Olsen J: The risk of multiple sclerosis in bereaved parents: a nationwide cohort study in Denmark. Neurology 2004;62:726-729.

-31 Simmons RD, Ponsonby AL, van der Mei IA, Sheridan P: What affects your MS? Responses to an anonymous, Internet-based epidemiological survey. Mult Scler 2004;10:202211.

-32 Ackerman KD, Stover A, Heyman R, Anderson BP, Houck PR, Frank E, Rabin BS, Baum A: 2002 Robert Ader New Investigator award. Relationship of cardiovascular reactivity, stressful life events, and multiple sclerosis disease activity. Brain Behav Immun 2003;17:141-151.

-33 Buljevac D, Hop WC, Reedeker W, Janssens AC, van der Meché FG, van Doorn PA, Hintzen RQ: Self reported stressful life events and exacerbations in multiple sclerosis: prospective study. BMJ 2003;327:646.
34 Ackerman KD, Heyman R, Rabin BS, Anderson BP, Houck PR, Frank E, Baum A: Stressful life events precede exacerbations of multiple sclerosis. Psychosom Med 2002;64:916-920.

35 Mohr DC, Goodkin DE, Nelson S, Cox D, Weiner M: Moderating effects of coping on the relationship between stress and the development of new brain lesions in multiple sclerosis. Psychosom Med 2002;64:803-809.

36 Mohr DC, Goodkin DE, Bacchetti P, Boudewyn AC, Huang L, Marrietta P, Cheuk W, Dee B: Psychological stress and the subsequent appearance of new brain MRI lesions in MS. Neurology 2000;55:55-61.

37 Kroencke DC, Denney DR: Stress and coping in multiple sclerosis: exacerbation, remission and chronic subgroups. Mult Scler 1999;5:89-93.

38 Schwartz CE, Foley FW, Rao SM, Bernardin LJ, Lee H, Genderson MW: Stress and course of disease in multiple sclerosis. Behav Med 1999;25:110-116.

39 Palumbo R, Fontanillas L, Salmaggi A, la Mantia L, Milanese C: Stressful life events and multiple sclerosis: a retrospective study. Ital J Neurol Sci 1998;19:259-260.

40 Gasperini C, Grasso MG, Fiorelli M, Millefiorini E, Morino S, Anzini A, Colleluori A, Salvetti M, Buttinelli C, Pozzilli C: A controlled study of potential risk factors preceding exacerbation in multiple sclerosis. J Neurol Neurosurg Psychiatry 1995;59:303-305.

41 Morrison W, Nelson J: Environmental trig gers in multiple sclerosis: fact or fallacy? Axone 1994;16:23-26.

42 Nisipeanu P, Korczyn AD: Psychological stress as risk factor for exacerbations in multiple sclerosis. Neurology 1993;43:1311-1312.

43 Warren S, Warren KG, Cockerill R: Emotional stress and coping in multiple sclerosis (MS) exacerbations. J Psychosom Res 1991; 35:37-47.

44 Grant I, Brown GW, Harris T, McDonald WI, Patterson T, Trimble MR: Severely threatening events and marked life difficulties preceding onset or exacerbation of multiple sclerosis. J Neurol Neurosurg Psychiatry 1989;52:8-13.

-45 Warren S, Greenhill S, Warren KG: Emotional stress and the development of multiple sclerosis: case-control evidence of a relationship. J Chronic Dis 1982;35:821-831.

46 Warren SA, Warren KG, Greenhill S, Paterson M: How multiple sclerosis is related to animal illness, stress and diabetes. Can Med Assoc J 1982;126:377-382, 385.

47 Heesen C, Gold SM, Huitinga I, Reul JM: Stress and hypothalamic-pituitary-adrenal axis function in experimental autoimmune encephalomyelitis and multiple sclerosis: a review. Psychoneuroendocrinology 2007;32: 604-618.

48 Dhabhar FS: Enhancing versus suppressive effects of stress on immune function: implications for immunoprotection and immunopathology. Neuroimmunomodulation 2009; 16:300-317.
49 Gold SM, Mohr DC, Huitinga I, Flachenecker P, Sternberg EM, Heesen C: The role of stress-response systems for the pathogenesis and progression of MS. Trends Immunol 2005;26:644-652.

50 Zorzon M, de Masi R, Nasuelli D, Ukmar M, Mucelli RP, Cazzato G, Bratina A, Zivadinov $\mathrm{R}$ : Depression and anxiety in multiple sclerosis: a clinical and MRI study in 95 subjects. J Neurol 2001;248:416-421.

51 Fassbender K, Schmidt R, Mössner R, Kischka U, Kühnen J, Schwartz A, Hennerici M: Mood disorders and dysfunction of the hypothalamic-pituitary-adrenal axis in multiple sclerosis: association with cerebral inflammation. Arch Neurol 1998;55:66-72.

52 Pakenham KI: Making sense of illness or disability: the nature of sense making in multiple sclerosis (MS). J Health Psychol 2008;13: 93-105.

53 D’Souza M, Kappos L, Czaplinski A: Reconsidering clinical outcomes in multiple sclerosis: relapses, impairment, disability and beyond. J Neurol Sci 2008;274:76-79.

54 Li DK, Li MJ, Traboulsee A, Zhao G, Riddehough A, Paty D: The use of MRI as an outcome measure in clinical trials. Adv Neurol 2006;98:203-226.

55 Cotton F, Weiner HL, Jolesz FA, Guttmann CR: MRI contrast uptake in new lesions in relapsing-remitting MS followed at weekly intervals. Neurology 2003;60:640-646.

56 Lee MA, Smith S, Palace J, Matthews PM: Defining multiple sclerosis disease activity using MRI $\mathrm{T}_{2}$-weighted difference imaging. Brain 1998;121:2095-2102.

57 Filippi M: Linking structural, metabolic and functional changes in multiple sclerosis. Eur J Neurol 2001;8:291-297.

58 Barnett MH, Prineas JW: Relapsing and remitting multiple sclerosis: pathology of the newly forming lesion. Ann Neurol 2004;55: 458-468.

59 Alonso G: Prolonged corticosterone treatment of adult rats inhibits the proliferation of oligodendrocyte progenitors present throughout white and gray matter regions of the brain. Glia 2000;31:219-231.

60 Khorchid A, Fragoso G, Shore G, Almazan G: Catecholamine-induced oligodendrocyte cell death in culture is developmentally regulated and involves free radical generation and differential activation of caspase-3. Glia 2002;40:283-299.

61 Zhang LX, Levine S, Dent G, Zhan Y, Xing G, Okimoto D, Kathleen Gordon M, Post RM, Smith MA: Maternal deprivation increases cell death in the infant rat brain. Brain Res Dev Brain Res 2002;133:1-11.

62 Butts BD, Houde C, Mehmet H: Maturationdependent sensitivity of oligodendrocyte lineage cells to apoptosis: implications for normal development and disease. Cell Death Differ 2008; 15:1178-1186. 